\title{
The fate of extracellular polysaccharide from Pseudomonas phaseolicola in leaves and leaf extracts from halo-blight susceptible and resistant bean plants (Phaseolus vulgaris L.)
}

\author{
F. E. EL-BANOBY, K. RUDOLPH \\ Institut für Pfanzenpathologie und Pflanzenschutz der Universität, Grisebachstrasse 6, D-3400 Göttingen, \\ Federal Republic of Germany
}

and K. MENDGEN

Fakultät für Biologie der Universität Konstanz, Lehrstuhl für Phytopathologie, Postfach 5560, D.7750 Konstanz, Federal Republic of Germany

(Accepted for publication September 1980)

Purified extracellular polysaccharide (EPS) from Pseudomonas phaseolicola was infiltrated into the mesophyll of bush bean leaves (Phaseolus vulgaris L.). The EPS disappeared from the intercellular spaces of the halo-blight resistant breeding line $0212 \mathrm{~h}$ after infiltration. Simultaneously, the visible water-soaked spots had vanished. By contrast, the intercellular spaces of the halo-blight susceptible cultivar Red Kidney were still completely filled with EPS 3 days after infiltration, and the water-soaked leaf-areas persisted. The EPS formed a stable network in the intercellular spaces of Red Kidney, whereas small floccules were observed in the incompatible system.

In vitro studies showed that the intercellular fluid (IF) from the trifoliates of breeding line 02 partially degraded the EPS, whereas IF from cultivar Red Kidney did not. EPS which had been incubated with IF from resistant leaves completely lost its capacity to induce persistent water-soaked spots. It is concluded, therefore, that the resistance of bean leaves towards persistent water-soaking caused by bacterial EPS was due to enzymatic degradation and inactivation of the introduced EPS.

\section{INTRODUCTION}

Extracellular polysaccharides (EPS) may play an important role during pathogenesis of bacterial leaf diseases [16]. Thus; it has been demonstrated that the EPS from phytopathogenic pseudomonads and xanthomonads induced persistent watersoaking in susceptible leaves of their host plants but not in any other plant tested [3]. The host-specific effect of the EPS at the cultivar level [2] became very clear after further purification $[4,5]$. The purified EPS from Pseudomonas phaseolicola induced persistent water-soaking only in halo-blight susceptible bean cultivars. In order to study the mechanism(s) of resistance towards EPS, susceptible and resistant bean leaves, which had been infiltrated with EPS, were examined using the electron microscope. In vitro studies were also carried out to study a possible degradation or inactivation of bacterial EPS by leaf extracts.

\section{MATERIALS AND METHODS}

\section{(1) Ultrastructural studies}

Highly purified extracellular polysaccharide (EPS) was obtained from culture filtrates of Pseudomonas phaseolicola isolate FV-75-8a according to El-Banoby and 
Rudolph [4]. The first trifoliates of the halo-blight susceptible cultivar Red Kidney and the halo-blight resistant breeding line 02 of bush bean (Phaseolus vulgaris L.) were infiltrated with the purified EPS $\left(15 \mathrm{mg} \mathrm{ml}^{-1}\right)$, using a hypodermic syringe [8]. The EPS-infiltrated areas had a size of approximately $20 \mathrm{~mm}^{2}$. The origin of the bean seeds has been described previously [3]. The treated plants were then covered with plastic bags [15] and maintained in a growih chamber at $20^{\circ} \mathrm{C}$ (under HQL lamps, which provided 9000 lux at plant height ( $16 \mathrm{~h}$ day). Small pieces of leaf tissue $(c .2 \times 4 \mathrm{~mm})$ were cut out of the EPS-infiltrated area at different time intervals. The leaf pieces were immediately fixed with glutaraldehyde followed by osmium tetroxide $[10,18]$. Ultra thin sections were contrasted with uranyl acetate and lead citrate [11] and examined with a Zeiss EM 10 electron microscope at $60 \mathrm{kV}$.

\section{(2) In vitro degradation of the EPS}

Intercellular fluid (IF) of the trifoliates of Red Kidney and 02 was obtained by centrifugation according to Klement [9] and Stall \& Cook [19], following infiltration with $0.034 \mathrm{M}$ phosphate buffer $(\mathrm{pH} 7.0)$ in $0.85 \% \mathrm{NaCl}$. For infiltration with buffer the detached leaves were enclosed in special glass containers (designed by H. Lehmann*) which were submerged in the buffer in a desiccator, evacuated with an aspirator for $15 \mathrm{~min}$, after which the vacuum was slowly released. The IF was filtered through a sintered glass filter (Schott + Gen G5) and concentrated at $2{ }^{\circ} \mathrm{C}$ to one-fifth of the original volume by membrane filters (Sartorius, Type SM.12136). Thus most of the compounds with a molecular weight below $10^{4}$ daltons were removed. The concentrated IF fractions were sterilized through a bacterial filter (Schleicher \& Schüll, No. 375208).

Two ml of the concentrated IF from each cultivar were separately added to $20 \mathrm{ml}$ suspension of sterilized $P$. phaseolicola EPS $(20 \mathrm{mg}$ ) in $0.034 \mathrm{M}$ phosphate buffer $(\mathrm{pH}$ 7.0 ) and incubated at $27^{\circ} \mathrm{C}$. At intervals of $30 \mathrm{~min}, 1 \mathrm{ml}$ of the reaction mixture was removed and added to $3 \mathrm{ml}$ of $96 \%$ ethanol. Ethanol stopped any enzymatic degradation of EPS and precipitated the residual high molecular polysaccharides. After $30 \mathrm{~min}$, the ethanol precipitate was separated by centrifugation at $6 \times 10^{3} \mathrm{~g}$. Content of free sugars was determined in the supernatant and of total sugars in the precipitate according to Bell [1].

During a second group of experiments the liberation of free sugars during the first $3 \mathrm{~h}$ of incubation was studied more extensively. The IF was concentrated to half of the original volume.

(3) Biological activity of EPS after incubation with leaf extracts

IF from Red Kidney and 02 (2 $\mathrm{ml}$ of each) were separately added to $10 \mathrm{ml}$ of sterilized EPS $\left(20 \mathrm{mg}\right.$ ) and incubated for $6 \mathrm{~h}$ at $27^{\circ} \mathrm{C}$. The reactions were stopped by the addition of $30 \mathrm{ml}$ ethanol. The precipitated preparations were centrifuged, dialyzed against double distilled water and lyophilized. The lyophilized preparations were dissolved in water at a concentration of $10 \mathrm{mg} \mathrm{ml}^{-1}$ and infiltrated into Red Kidney leaves according to Rudolph [15]. The biological activity of these

*We thank Dr H. Lehmann for providing the glass vessels. 
preparations was compared with untreated EPS and expressed as the number of persistent water-soaked spots 1 to 3 days after infiltration.

\section{RESULTS}

\section{Ultrastructural studies}

Immediately after infiltration, the leaf tissue was intact and no damage of organelles could be observed. The intercellular spaces were completely filled with the EPS (Plates 1 and 2).

Three hours after infiltration, the EPS in the resistant breeding line 02 began to aggregate. The cytoplasm appeared undisturbed (Plate 3).

Six hours after infiltration, aggregation of EPS had increased in the resistant cultivar and the amount of detectable EPS had simultaneously decreased. The plasmalemma had separated from the cell walls (Plate 4, indicated by arrow). In the susceptible cultivar Red Kidney, the polysaccharide formed a net-like structure without any visible decrease in concentration. The membranes were unchanged.

Even less EPS was observed in the intercellular spaces of the resistant breeding line $029 \mathrm{~h}$ after infiltration (Plate 5), and after $12 \mathrm{~h}$ EPS was very rarely detected. At the same time, the water-soaked spots had completely disappeared and the separation of the plasmalemma from the cell wall was more apparent, indicating a partial plasmolysis. In Red Kidney the water-soaked spots were still present $12 \mathrm{~h}$ after infiltration.

During the following period, up to 3 days after infiltration, the appearance of both cultivars changed very little. The cells of 02 showed plasmolysis without any damage of other cell components (Plate 6). The intercellular spaces of Red Kidney remained filled with EPS and neither damage of the cell membranes nor disorganization of the cell organelles was observed (Plate 7). Water-soaking was still apparent in the leaves of Red Kidney. However, changes were also observed in the susceptible cultivar Red Kidney. The appearance of the EPS changed from a rather uniform granular appearance to a network (compare Plate 1 with Plate 7).

In vitro degradation of EPS

When EPS was incubated with intercellular fluid (IF) which was concentrated to onefifth of the original volume, a marked EPS-degradation occurred only with IF from 02. First appearance and amount of liberated free sugars corresponded with the decrease of precipitable polysaccharides, as shown in Fig. 1, where only the changes in sugar concentrations ( $\Delta \mu \mathrm{g}$ sugar) were plotted. The time-course of the degradation was also different. IF from resistant bean leaves 02 led to an increase in soluble sugars after 0.5 to $1.0 \mathrm{~h}$ incubation, whereas an increase in insoluble sugars was not seen with IF from susceptible leaves (Red Kidney) until 1.5 to $2.0 \mathrm{~h}$ after incubation. The increase in soluble sugars was always paralleled by a decrease in ethanol-precipitated polysaccharide (Fig. 1).

The results of the second group of experiments, where the IF was concentrated to one-half of the original volume, are shown in Table 1. The results of 3 independent experiments with cv. Red Kidney and 5 independent experiments with cv. 02 are 


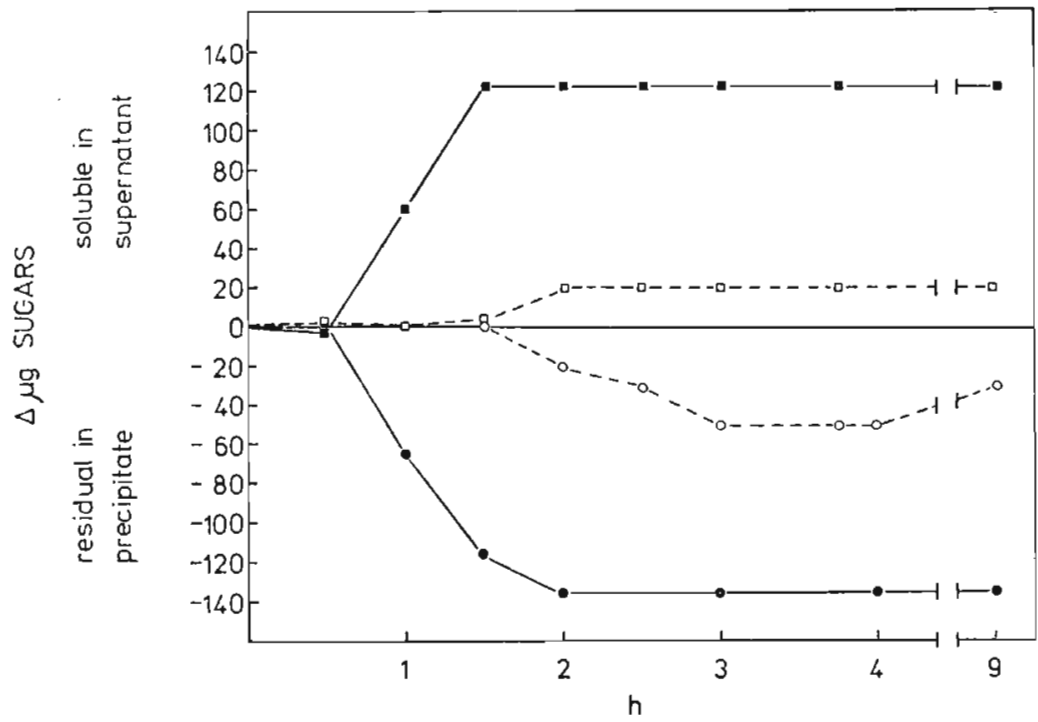

Fig. 1. Effect of the intercellular fluid (IF) on degradation of the EPS from Pseudomonas phaseolicola at $27^{\circ} \mathrm{C}$. Soluble sugars liberated by IF from 02 (a) or from Red Kidney ( $\square$ ), residual polysaccharides after treatment with IF from 02 ( $)$ or from Red Kidney (0). The curves represent sugar contents of the samples after subtraction of sugar contents at zero time.

TABLE 1

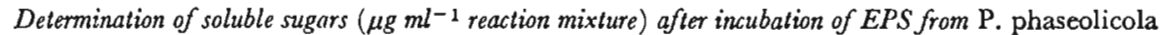
with intercellular fuid (IF) from Red Kidney $R K$ or breeding line 02 at $27^{\circ} \mathrm{C}$

\begin{tabular}{|c|c|c|c|c|c|c|}
\hline \multirow[b]{2}{*}{ Treatment } & \multirow{2}{*}{$\begin{array}{c}\text { Incubation } \\
\text { (h) }\end{array}$} & \multicolumn{5}{|c|}{ Experiment no. } \\
\hline & & 1 & 2 & 3 & 4 & 5 \\
\hline EPS & $\begin{array}{l}1 \\
2 \\
3\end{array}$ & $\begin{array}{l}0^{a} \\
1 \\
1\end{array}$ & $\begin{array}{r}0 \\
-\quad 1 \\
0\end{array}$ & $\begin{array}{l}0 \\
0 \\
2\end{array}$ & & \\
\hline IF of RK & $\begin{array}{l}1 \\
2 \\
3\end{array}$ & $\begin{array}{r}2 \\
11 \\
-7\end{array}$ & $\begin{array}{r}0 \\
-6 \\
0\end{array}$ & $\begin{array}{r}14 \\
14 \\
-8\end{array}$ & & \\
\hline IF of 02 & $\begin{array}{l}1 \\
2 \\
3\end{array}$ & $\begin{array}{r}1 \\
2 \\
-7\end{array}$ & $\begin{array}{r}-2 \\
4 \\
0\end{array}$ & $\begin{array}{r}-8 \\
-34 \\
-4\end{array}$ & $\begin{array}{l}2 \\
2 \\
8\end{array}$ & $\begin{array}{r}20 \\
24 \\
8\end{array}$ \\
\hline $\mathrm{EPS}+\mathrm{IF}$ of RK & $\begin{array}{l}1 \\
2 \\
3\end{array}$ & $\begin{array}{r}1 \\
11 \\
14\end{array}$ & $\begin{array}{l}\overline{20}^{\circ} \\
22\end{array}$ & $\begin{array}{r}20 \\
20 \\
8\end{array}$ & & \\
\hline $\mathrm{EPS}+\mathrm{IF}$ of 02 & $\begin{array}{l}1 \\
2 \\
3\end{array}$ & $\begin{array}{r}-6 \\
24 \\
56\end{array}$ & $\begin{array}{r}-2 \\
24 \\
92\end{array}$ & $\begin{array}{l}102 \\
104 \\
154\end{array}$ & $\begin{array}{r}76 \\
100 \\
>424\end{array}$ & $\begin{array}{r}-18 \\
20 \\
116\end{array}$ \\
\hline
\end{tabular}

${ }^{a}$ Values represent sugar contents of the samples after subtraction of sugar contents at zero time.

${ }^{\mathrm{b}}$ Not determined. 
tabulated. It should be noted that only a portion of the polysaccharide was completely hydrolysed (on average $17 \%$ with IF from 02 and $1.5 \%$ with IF from Red Kidney, as can be calculated from the data of Table 1). There was practically no increase in free sugars observed after incubation of EPS without IF. Some variation occurred after incubation of IF without EPS; small increases or decreases of free sugars were recorded. Only in the combination of EPS with IF from 02 a marked increase of free sugars occurred in all of the 5 experiments at 2 and $3 \mathrm{~h}$ after incubation.

\section{Biological activity of EPS after incubation with leaf extracts}

The studies on the degradation of EPS by enzymes from IF indicated that 83 to $98.5 \%$ EPS could still be precipitated by ethanol (Table 1). However, a partial hydrolysis of the high molecular weight EPS could not be detected by this method. The biological activity, therefore, was tested by infiltration of Red Kidney leaves with the treated EPS. EPS which had been incubated with IF from Red Kidney leaves did not show a significant reduction in biological activity (Table 2). In

TABLE 2

\begin{tabular}{|c|c|c|c|c|}
\hline \multirow[b]{2}{*}{ Treatment } & \multicolumn{4}{|c|}{$\begin{array}{l}\text { Number of persistent water-soaked spots } \\
\text { (Days after infiltration) }\end{array}$} \\
\hline & 0 & 1 & 2 & 3 \\
\hline water & 24 & 4 & 2 & 0 \\
\hline EPS & 24 & 22 & 20 & 19 \\
\hline EPS + IF of "RK" & 24 & 20 & 19 & 19 \\
\hline EPS + IF of " 02 " & 24 & 9 & 5 & 4 \\
\hline IF of "RK" & 24 & 3 & 2 & 0 \\
\hline IF of " 02 " & 24 & 3 & 2 & $0+a$ \\
\hline
\end{tabular}

contrast, EPS which had been incubated with IF from 02 showed a drastically reduced biological activity. Three days after infiltration the number of persistent water-soaked spots was only $25 \%$ of the untreated EPS (Table 2), although the same concentration of EPS had been applied.

These results indicated that the intercellular fluid from the resistant breeding line 02 not only degraded part of the bacterial EPS to free sugars but also attacked the residual high molecular weight EPS so that the biological activity was greatly reduced.

\section{DISCUSSION}

Water-soaking of the normally air-filled intercellular spaces of leaf mesophyll is regarded as an essential status for the build up of high bacterial populations in plant leaves [16]. In susceptible bean cultivars, the appearance of water-soaking is typical for the earliest symptoms of disease [20]. In the resistant cultivars, symptoms of disease may not be expressed at all, or only as a necrosis (hypersensitivity) at the site 
of infection, or initial water-soaked spots that dry rapidly to resemble necrotic spots $[12,13,20]$.

Earlier studies showed that disease susceptibility of bean cultivars was correlated with their reaction with bacterial exudates from infected bean stems [15] or extracellular polysaccharides from culture filtrates [5]. This correlation has been reported not only for halo-blight of bean but also for several other host-parasite combinations, e.g. Pseudomonas lachrymans on cucumber, Xanthomonas malvacearum on cotton, and $X$. translucens $\mathrm{f}$. sp. cerealis on different cereals [3]. The underlying mechanism of this host-cultivar-specific effect of the EPS is unknown.

The ultrastructural studies of bean leaves infiltrated with EPS, reported here, revealed a close correlation between water-soaked leaf areas and the presence of polysaccharides within the intercellular spaces. The disappearance of the polysaccharides from the intercellular spaces was associated with the disappearance of the water-soaked appearance of the tissue. Thus, in the susceptible cultivar Red Kidney, 3 days after infiltration with EPS from $P$. phaseolicola, the leaves were still water-soaked and the intercellular spaces were filled with EPS (Plate 7). In the resistant breeding line 02 no persistent water-soaking occurred and, concomitantly the EPS from the intercellular spaces disappeared (Plate 6). Sigee \& Epton [18] described a pale electron-opaque material around the bacteria of $P$. phaseolicola in the intercellular spaces of compatible combinations, which was not visible in resistant bean cultivars. This opaque material around the bacteria may be identical with the EPS reported here.

In the water-soaked tissue of the susceptible cultivar Red Kidney, the intact EPS apparently never entered the plant cells, nor did it cause any visible damage or alteration to the plasma membranes, chloroplasts, endoplasmatic reticulum or nucleus (Plates 1 and 7). It could be concluded, therefore, that the EPS did not primarily alter the permeability of the cell membranes of the susceptible cultivars. It is also hard to imagine that enhanced permeability and increased leakage of water out of the plant cells would result in persistent water-soaking, as such water would soon be lost by transpiration resulting in dried or necrotized tissue. This effect is caused by several toxins of plant pathogens [14]. It would seem more likely, therefore, that water, which travels through the leaves with the transpiration stream, is captured by the EPS in the intercellular spaces. The high water-holding capacity of exudates from phytopathogenic bacteria has been mentioned earlier [6]. Imam \& Abd-Allah [7] reported that an extracellular polysaccharide from Bacillus polymyxa was able to absorb twice its weight of water.

The rather rapid disappearance of the EPS from the intercellular spaces of the resistant breeding line 02 (Plates 6 and 7) appears to be attributable to degradation. EPS degradation could be demonstrated in the in vitro studies with the so-called intercellular fluid (IF) reported here. The rather tedious procedure of obtaining IF from leaves in large quantities was chosen because this fluid practically reflects the milieu in which the interaction between bacteria and host plant takes place. It could be suggested, therefore, that the differences in EPS-degradation and inactivation determined between the two bean cultivars also existed in vivo. The fast disappearance of infiltrated EPS from the intercellular spaces of the resistant cultivar could thus be explained. In any case, the observation that the residual EPS had nearly 

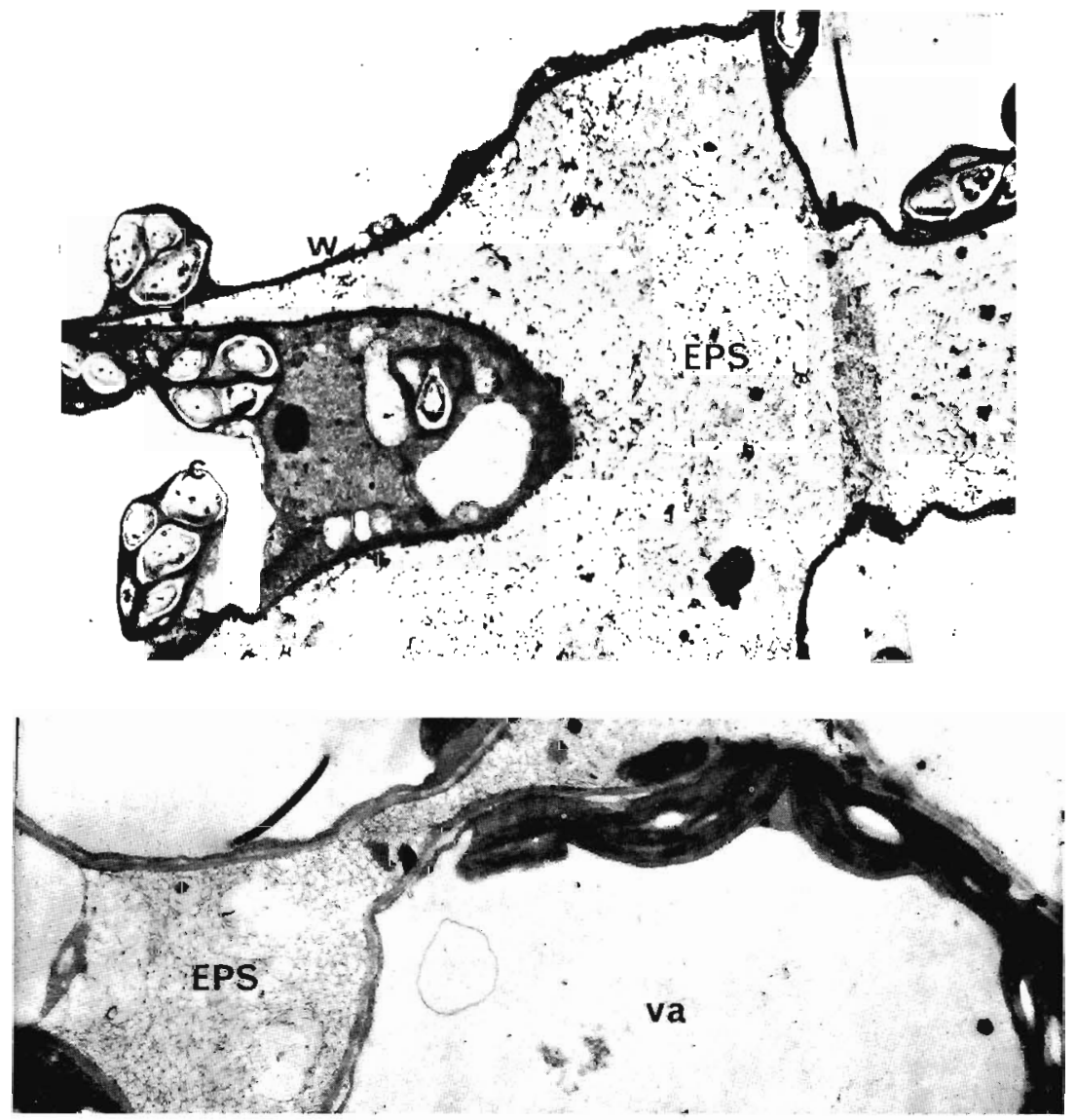

Abbreviations used: c, chloroplast; $\mathrm{cm}$, cell membrane; EPS, extracellular polysaccharide; is, intercellular space; va, vacuole; and $w$, cell wall.

Plates 1 and 2. Cross section of leaves from RK (Plate 1) and 02 (Plate 2) $0 \mathrm{~h}$ aftcr EPS infiltration. The EPS filled the intercellular spaces and the cells were unchanged. $\times 3750$ and 4725 , respectively. 


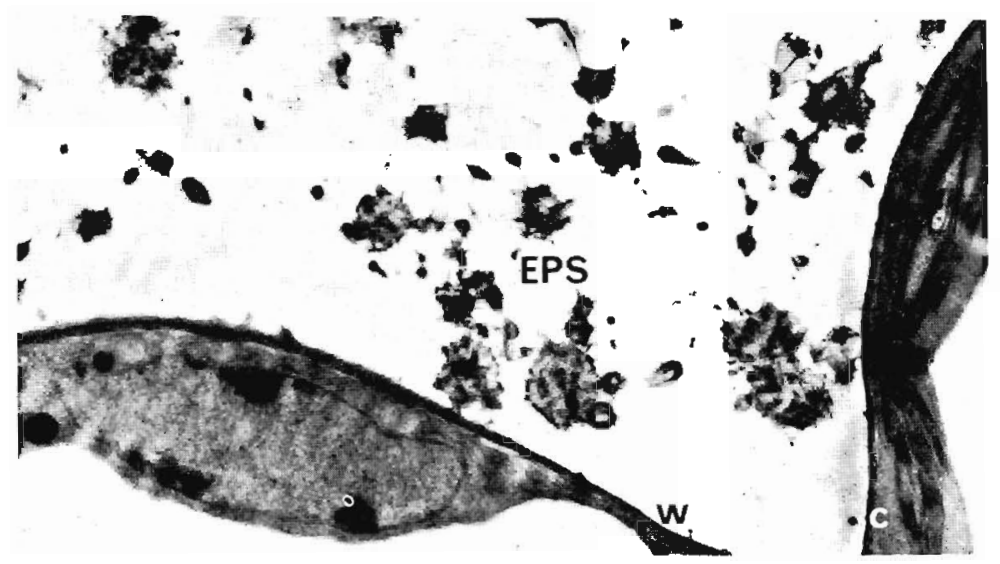

Plate 3. Aggregation of EPS in the intercellular spaces of $023 \mathrm{~h}$ after infiltration. The cells remained unchanged. $\times 7500$.

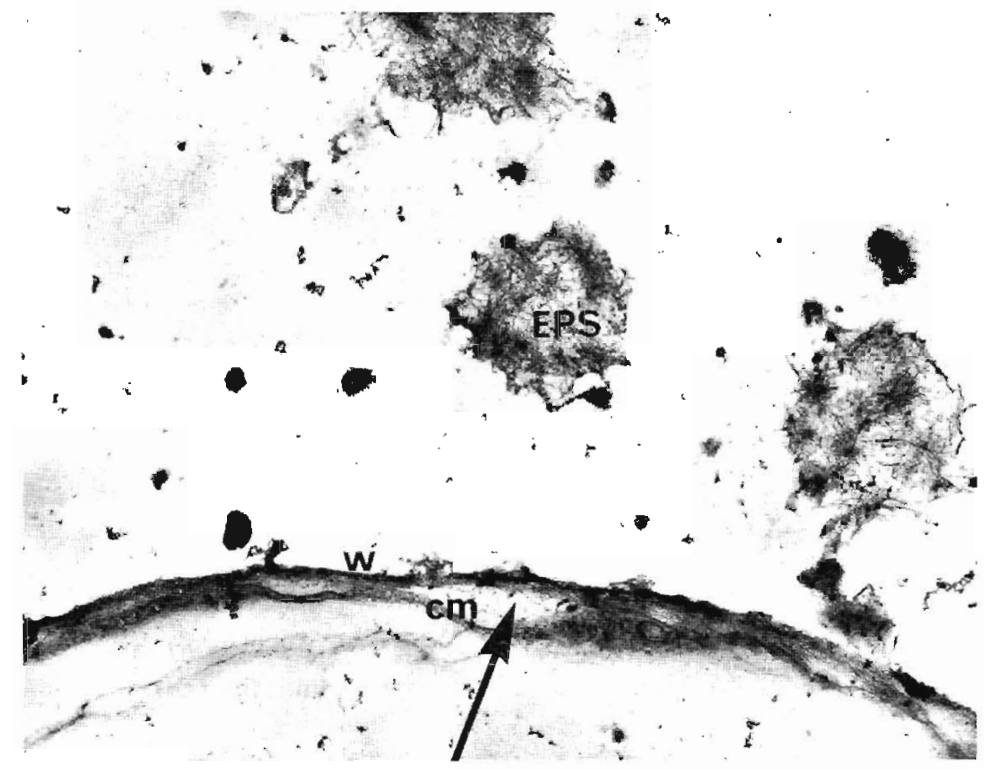

PlAtE 4. Advanced stage of EPS-aggregation in the intercellular spaces of $026 \mathrm{~h}$ after infiltration. The amount of EPS decreased and the cell membrane $(\mathrm{cm})$ began to separate from the cell wall (arrow). $\times 18750$. 


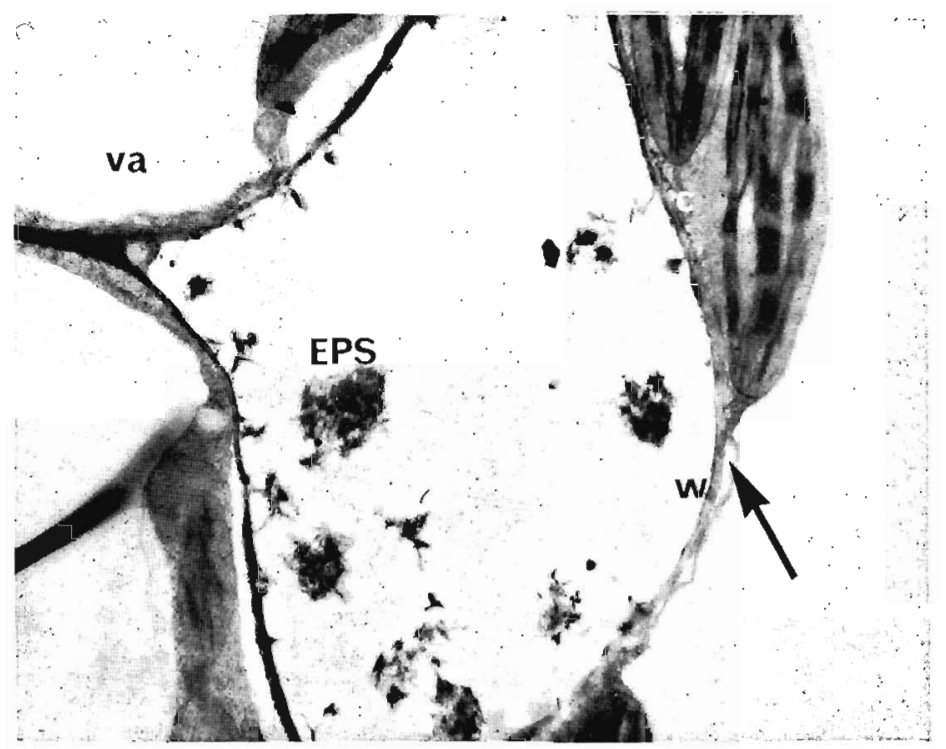

PLATE 5. Further decrease of EPS in the intercellular space of $029 \mathrm{~h}$ after infiltration. arrow labels the plasmalemma where it has withdrawn from the cell wall. $\times 9450$.

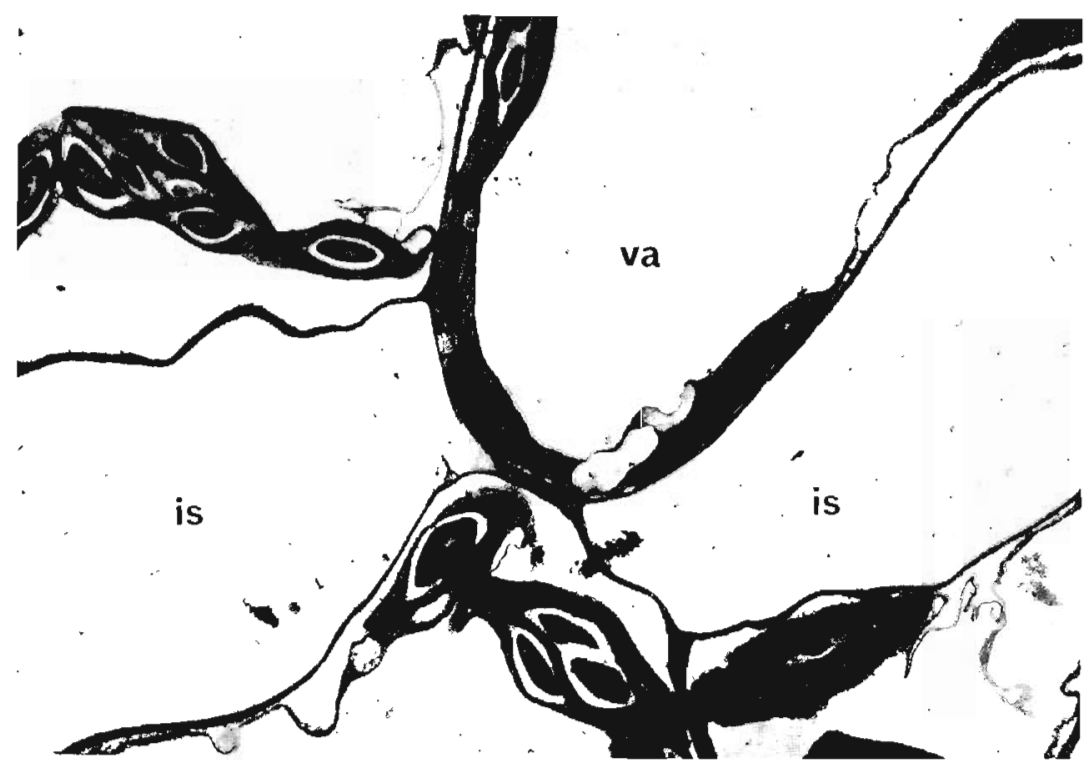

PLATE $6.72 \mathrm{~h}$ after infiltration, the EPS had completsly disappeared from the intercellular spaces of 02 , the mesophyll showed plasmolysis. $\times 4725$ 


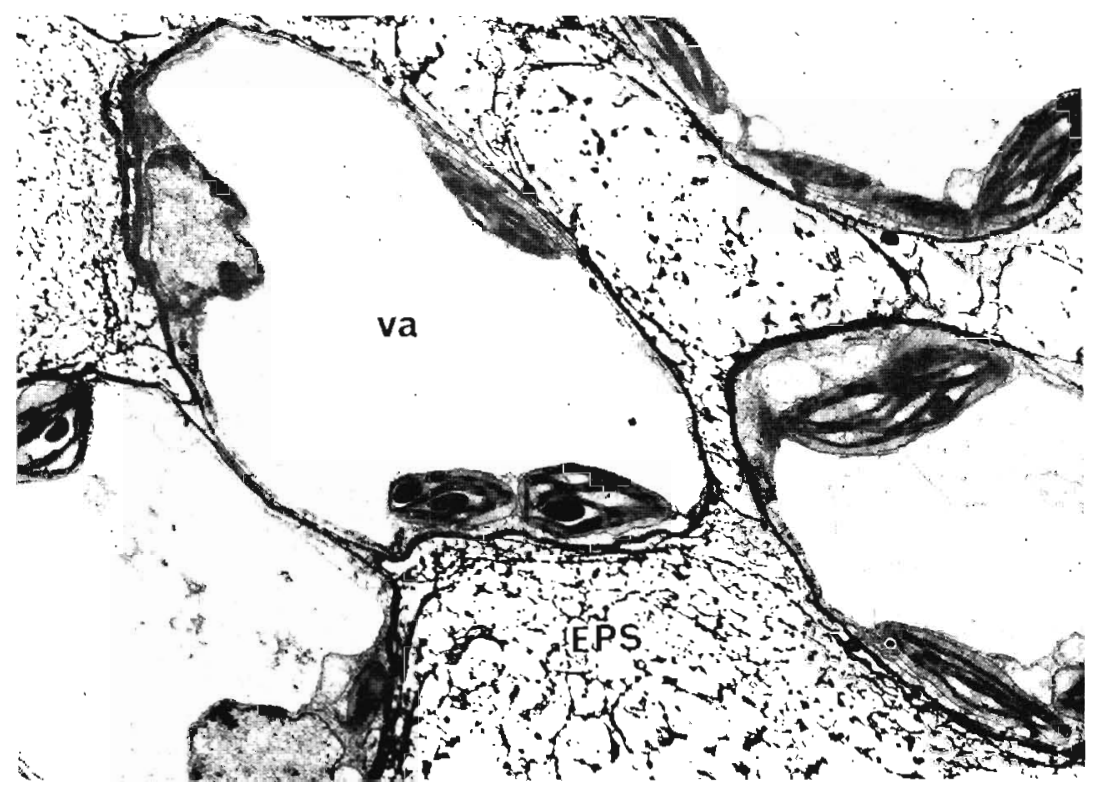

J'LATE 7. Intercellular spaces of RK, $72 \mathrm{~h}$ after infiltration, still filled with EPS. The cells remained unchanged. $\times 3750$. 
completely lost its biological activity can explain the disappearance of the watersoaked spots in the resistant cultivar.

Another observation which may help to explain the fast disappearance of EPS from the intercellular spaces of the resistant cultivar is the obvious failure of the EPS to form a stable gel in the incompatible system. Thus, the EPS formed a net-like structure only in the intercellular spaces of Red Kidney (Plate 7), whereas in 02 the EPS aggregated to small floccules soon after infiltration (Plates 3, 4 and 5).

Since the IF also contributed to the polysaccharide content of the reaction mixture during in vitro degradation studies, the estimated free sugars may have been partially liberated from plant polysaccharides. Therefore, studies were initiated to determine the degradation of ${ }^{14} \mathrm{C}$-labelled bacterial EPS.

The in vitro experiments only showed a partial EPS-degradation. On the other hand, EM-observations indicated a complete disappearance of EPS in resistant leaves. This may have been caused by cell wall bound enzymes. From the complete disappearance of EPS in vivo a high increase of soluble sugars could be expected, since the infiltrated solution contained $15 \mathrm{mg} \mathrm{EPS} \mathrm{ml}^{-1}$. The resulting increase of osmotic potential may explain the observed plasmolysis in the resistant leaves. If similar processes take place during the initial bacterial multiplication in resistant leaf tissue, this effect might add to the inhibition of bacterial multiplication. That a high osmotic value can act as an inhibiting factor in bacterial multiplication in the intercellular spaces has been previously discussed [17]. In the studies reported here the plasmolysis was reversible, probably because after completion of EPS-degradation the free sugars were transported into the cells and gradually metabolized.

From the electron microscopic studies and the in vitro EPS-degradation experiments it may be concluded that the resistance of bean leaves from cv. 02 towards persistent water-soaking caused by bacterial EPS is due at least in part to enzymatic degradation and inactivation of the introduced EPS.

Thanks are due to the Studienmission der Arabischen Republik Ägypten and the Deutsche Forschungsgemeinschaft for financial support and to Dr J. B. Speakman for reading the manuscript.

\section{REFERENCES}

1. BeLL, D. J. (1955). Mono- and oligosaccharides and acidic monosaccharide derivatives. In Modern Methods of Plant Analysis. Ed. by K. Paech \& M. V. Traccy, pp. 1-54, Springer Verlag, Berlin-Göttingen and Heidelberg.

2. El-Banoby, F. E. \& Rudolph, K. (1979). A polysaccharide from liquid cultures of Pseudomonas phaseolicold which specifically induces water-soaking in bean leaves (Phaseolus vulgaris L.). Phytopathologische Zeitschrift 95, 38-50.

3. El-Banoby, F. E. \& Rudolph, K. (1979). Induction of water-soaking in plant leaves by extracellular polysaccharides from phytopathogenic pseudomonads and xanthomonads. Physiological Plant Pathology 15, 341-349.

4. El-Banoby, F. E. \& Rudolph, K. (1980). Purification of extracellular polysaccharides from Pseudomonas phaseolicold which induce water-soaking in bean leaves. Physiological Plant Pathology 16, $425-437$.

5. El-Banoby, F. E., Rudolph, K. \& Hürtermann, A. (1980). Biological and physical properties of an extracellular polysaccharide from Pseudomonas phaseolicola. Physiological Plani Pathology 17, 291-301. 
6. Henrick, H. G. (1956). Exudates produced by phytopathogenic bacteria. Phytopathology 46, 14-15 (Abstr.)

7. Imam, G. M. \& ABD-Allah, N. M. (1974). Fructosan, a new soil conditioning polysaccharide isolated from the metabolites of Bacillus polymyxa AS-1 and its clinical applications. Egyptian Journal of Botany 17, 19-26.

8. KLEMENT, Z. (1963). Method for the rapid detection of the pathogenicity of phytopathogenic pseudomonads. Nature 199, 299-300.

9. Klement, Z. (1965). Method of obtaining fluid from intercellular spaces of foliage and the fluid's merit as substrate for phytobacterial pathogens. Phytopathology 55, 1033-1034.

10. Mendgen, K. (1973). Feinbau der Infektionsstrukturen von Uromyces phaseoli. Phylopathologische Zeilschrifı 78, 109-120.

11. Reynolds, E. S. (1963). The use of lead citrate at high $\mathrm{pH}$ as electron opaque stain in electron microscopy. Fournal of Biophysical and Biochemical Cytology 17, 208-212.

12. Roebuck, P., Sexton, R. \& Mansfield, J. W. (1978). Ultrastructural observations on the development of the hypersensitive reaction in leaves of Phaseolus vulgaris cv. Red Mexican inoculated with Pseudomonas phaseolicola (race 1). Physiological Plant Pathology 12, 151-157.

13. Rudolph, K. (1972). Die Anfälligkeit von Buschbohnensorten (Phaseolus vulgaris var. nanus L.) gegen die durch Pseudomonas phaseolicola (Burkh.) Dowson hervorgerufene Fettfleckenkrankheit. Nachrichtenblatl des Deutschen Pflanzenschul zdienstes 24, 49-51.

14. Rudolph, K. (1976). Non-specific toxins. In Encyclopedia of Plant Physiology, New Series, Vol. 4 : Physiological Plant Pathology, Ed. by R. Heitefuss \& P. H. Williams, pp. 270-315. Springer Verlag, Berlin, Heidelberg and New York.

15. Rudolph, K. (1978). A host specific principle from Pseudomonas phaseolicola (Burkh.) Dowson, inducing water-soaking in bean leaves. Phytopathologische Zeitschrift 93, 218-226.

16. Rudolph, K. (1980). Multiplication of bacteria in leaf-tissue. Angewandte Botanik 54, 1-9.

17. Sasser, J. M., Miller, R. W. \& Fieldhouse, D. J. (1970). Osmotic potential, a controlling factor in the development of bacterial spot diseases. Phytopathology 60, 1311 (Abstr.).

18. SYGeE, D. C. \& EPTon, H. A. S. (1977). Ultrastructural changes in resistant and susceptible varieties of Phaseolus vulgaris following artificial inoculation with Pseudomonas phaseolicola. Physiological Plant Pathology 9, 1-8.

19. STALL, R. E. \& Gook, A. A. (1968). Inhibition of Xanthomonas vesicatoria in extracts from hypersensitive and susceptible pepper leaves. Phytopathology 58, 1584-1587.

20. Walker, J. G. \& Patel, P. N. (1964). Inheritance of resistance to halo blight of bean. Phytopalhology 54, 952-954. 